\title{
China-HP-SSST: Last Part of Growing Pains?
}

\author{
DUKGEUN AHN * \\ Seoul National University \\ MAURIZIO ZANARDI** \\ Lancaster University Management School
}

\begin{abstract}
In December 2012, Japan requested the establishment of a World Trade Organization (WTO) Panel regarding antidumping (AD) duties that China had imposed on high-performance stainless steel seamless tubes (HP-SSST). The European Union joined as a complainant in June 2013. To some degree, this dispute follows earlier ones involving China, as similar procedural and substantial issues were raised in previous cases. However, this was the first time that the WTO Panel rejected some important claims, only for those decisions to be reversed by the Appellate Body. Now that various rulings have clarified these legal issues, it remains to be seen if HP-SSST represents the last part of growing pains for Chinese authorities to learn about AD legal procedures.
\end{abstract}

\section{Introduction}

In December 2012, Japan requested the World Trade Organization (WTO) to establish a Panel regarding the antidumping (AD) duties that China had imposed on high-performance stainless steel seamless tubes (HP-SSST) a month earlier. As the second major exporter of these products, also targeted by the same AD measures, the European Union joined as a complainant in June 2013.

The Panel's decision was circulated early in 2015 and its ruling recognized that China had acted inconsistently with the WTO AD Agreement while at the same time rejecting some of the complainants' claims. As a result, all parties (i.e. China, European Union, and Japan) appealed the Panel's rulings. The Appellate Body upheld all the rulings in favor of the complainants and reversed most of the Panel's decisions in favor of the defendant. In the end, China lost the case on almost all issues. Considering the final outcome, the dispute China-High-Performance Stainless

\footnotetext{
*Email: dahn@snu.ac.kr.

**Email: m.zanardi@lancaster.ac.uk.

We are very grateful to Andrea Mastromatteo, Chad Bown, Carlo Cantore, Jennifer Hillman, Mislav Mataija, Julia Ya Qin, and Hylke Vandenbussche for their helpful comments. We also appreciate research assistance by Kyounghwa Kim and Pulum Kim at Seoul National University and the financial support from the National Research Foundation of Korea Grant (NRF 2014S1A3A2043505) as well as Seoul National University Asia Center (SNUAC-2015-008).
} 
Steel Seamless Tubes $^{1}$ is the last one to have reached the conclusion in a series of similar disputes against China's AD actions, and it repeats a familiar refrain (see Tables 3 and 5 for a summary): China has systematically acted inconsistently with the WTO AD Agreement, in particular with respect to fair comparison in dumping calculations, injury determination, and disclosure of essential facts. And the ongoing dispute brought about by Canada and focusing on the same substantive issues suggests that China has not repented. ${ }^{2}$

The similarities between these disputes will be highlighted in the next sections while trying to limit repetition of similar reasoning to a minimum. ${ }^{3}$ Instead, through the discussion of a specific aspect (i.e. definition of domestic like product) of this case and how it has (not) surfaced in previous disputes, we speculate that the complainants may have had grounds to claim that China had also acted inconsistently in another dimension. And it remains an open question why such an issue has not been pursued. At the same time, the legal and economic analysis will draw from previous arguments that WTO Panels, the Appellate Body, and the literature have put forward.

The rest of the paper is organized as follows. Section 2 provides the details of the case, product, industry, and a comparison with other cases. The key legal findings are summarized in Section 3 while Section 4 presents the legal and economic analysis of the Panel and Appellate Body's rulings. Section 5 concludes.

\section{Factual background for products and industry}

On 8 September 2011, pursuant to the requests by Jiangsu Wujin Stainless Steel Pipe Group Co. Ltd and Changshu Huaxin Pipe Co. Ltd, ${ }^{4}$ the Ministry of Commerce of the People's Republic of China (MOFCOM) initiated an AD investigation on HP-SSST products from the European Union and Japan, which are classified into Chinese HS codes 73044110, 73044910, 73045110, and 73045910 (although the final AD measures did not cover products under HS codes 73045110 and 73045910). MOFCOM used a one-year period between July 2010 and June 2011 for the dumping margin calculation and a three and a half year period from January 2008 to June 2011 for the injury determination. On 8 November 2012, MOFCOM found that the Japanese products accounted for

1 Panel Report, China-Measures Imposing Anti-Dumping Duties on High-Performance Stainless Steel Seamless Tubes (HP-SSST) from Japan, WT/DS454 (China-HP-SSST (Japan)); China-Measures Imposing Anti-Dumping Duties on High-Performance Stainless Steel Seamless Tubes (HP-SSST) from the European Union, DS460/R (China-HP-SSST (EU)).

2 China-Anti-dumping Measures on Imports of Cellulose Pulp from Canada, Request for Consultations (DS483), WT/DS483/1 (China-Cellulose Pulp).

3 Interested readers are referred to the previous articles that have discussed these final rulings: see Prusa and Vermulst (2014, 2015), Moore and Wu (2015), and Mitchell and Prusa (2016).

4 Three other domestic producers, Zhejiang Jiuli Hi-Tech Metals Co. Ltd., Jiangsu Yinhuan Precision Steel Tube Co. Ltd., and Baoshan Steel Co. Ltd., supported the AD petition (see Bown, 2016). 
$68 \%$ of the total imports and imposed AD duties of $9.2 \%$ for Sumitomo Metal Industries Ltd., $14.4 \%$ for Kobe Special Tube Co. Ltd., and $14.4 \%$ for all others. Against imports from the European Union that represented about $23 \%$ of total imports, ${ }^{5}$ MOFCOM imposed AD duties of $9.7 \%$ for Tubacex Tubos Inoxidables S.A., 11.1\% for Salzgitter Mannesmann Stainless Tubes Italia s.r.l., and $11.1 \%$ for all others.

As a major target of the AD measures, Japan immediately reacted within the framework of the WTO dispute settlement system. On 20 December 2012, Japan brought the consultation request on China-Measures Imposing AntiDumping Duties on High-Performance Stainless Steel Seamless Tubes from Japan (China-HP-SSST (Japan)), which became the second Japanese WTO dispute against China. ${ }^{6}$ On 13 June 2013, the European Union also requested consultation on China-Measures Imposing Anti-Dumping Duties on HighPerformance Stainless Steel Seamless Tubes from the European Union (ChinaHP-SSST (EU)), which became the third EU AD dispute against China. ${ }^{7}$

The product under investigation is HP-SSST with a carbon content of not less than $0.04 \%$ but not more than $1.2 \%$, a chromium content of more than $16 \%$, a nickel content of more than $7 \%$, a niobium content of not less than $0.2 \%$, a tensile strength of not less than $550 \mathrm{Mpa}$, and a yield strength of over $200 \mathrm{Mpa} .^{8}$ Due to the special composition of chemical elements, HP-SSST shows distinguishable features such as high endurance strength, structure stability, anti-steam oxidation, and corrosion resistance at high temperature. ${ }^{9}$ Such high performance characteristics make them used mainly in superheaters and reheaters of supercritical or ultra-supercritical boilers in power stations. HP-SSST is normally classified

5 WTO, G/ADP/N/237/CHN, 2-3 (dated 10 April 2013). In fact, EU exports of HP-SSST to China were worth some $€ 90$ million in 2009, but dropped to under $€ 20$ million in November 2012 (European Commission Press Release IP/13/772, 16 August 2013).

6 The first dispute raised by Japan was China-Measures Related to the Exportation of Rare Earths, Tungsten and Molybdenum (DS433) (China-Rare Earths). China has not yet brought a complaint against Japan in the WTO system.

7 The two earlier AD disputes are China - Provisional Anti-Dumping Duties on Certain Iron and Steel Fasteners from the European Union (DS407) (China-Fasteners) and China-Definitive Anti-Dumping Duties on X-Ray Security Inspection Equipment from the European Union (DS425) (China-X-Ray Equipment). As of June 2016, the European Union has brought seven cases against China. China has initiated four complaints against the European Union. On the other hand, there are three rulings concerning China's AD actions brought by the United States: China - Countervailing and Anti-Dumping Duties on Grain Oriented Flat-rolled Electrical Steel from the United States (DS414) (China-GOES); China-AntiDumping and Countervailing Duty Measures on Broiler Products from the United States (DS427) (ChinaBoiler Products); and China-Anti-Dumping and Countervailing Duties on Certain Automobiles from the United States (DS440) (China-Autos).

8 MOFCOM Announcement No. 72 of 2012 on the Final Ruling of the Anti-dumping Case against Imports of Certain High-performance Stainless Steel Seamless Tubes Originated in the EU and Japan, available at http://english.mofcom.gov.cn/sys/print.shtml?/policyrelease/buwei/201211/20121108432478 (visited 6 March 2016).

9 Ibid. 
Table 1. HP-SSST product identification

\begin{tabular}{|c|c|c|c|c|}
\hline Product & ASTM Grade & $\begin{array}{l}\text { China National Standard } \\
\text { GB5310-2008 }\end{array}$ & $\begin{array}{l}\text { Mannesmann serial } \\
\text { number }\end{array}$ & $\begin{array}{l}\text { Sumitomo serial } \\
\text { number }\end{array}$ \\
\hline $\mathrm{A}$ & TP347HFG & 08Cr18Ni11NbFG & DMV347HFG & $347 \mathrm{HFG}$ \\
\hline B & S30432 & $10 \mathrm{Cr} 18 \mathrm{Ni} 9 \mathrm{NbCu} 3 \mathrm{BN}$ & $\mathrm{DMV} 304 \mathrm{HCu}$ & Super304H \\
\hline $\mathrm{C}$ & TP310HNbN & $07 \mathrm{Cr} 25 \mathrm{Ni} 21 \mathrm{NbN}$ & DMV310N & HR3C \\
\hline
\end{tabular}

Source: Panel Report, China-HP-SSST, B-28.

Table 2. Market shares of subject imports

\begin{tabular}{lrrrr}
\hline \hline & \multicolumn{1}{c}{2008} & \multicolumn{1}{c}{2009} & \multicolumn{1}{c}{2010} & $01-06 / 2011$ \\
\hline Grade A & $1.45 \%$ & $0.00 \%$ & $0.00 \%$ & $0.00 \%$ \\
Grade B (over 70\% of product) & $89.48 \%$ & $96.65 \%$ & $90.49 \%$ & $97.63 \%$ \\
Grade C (bulk of 30\% of product) & $100.00 \%$ & $99.94 \%$ & $99.10 \%$ & $\begin{array}{r}90.69 \% \\
\text { 3 grades together }\end{array}$ \\
\hline \hline
\end{tabular}

Source: Table based on data in the Panel Report, China-HP-SSST.

into three categories, with different nomenclatures according to different national standards regimes and producers' designations, as shown in Table 1. Following the notation of the legal proceedings, in the following we also identify the different products by the letters $\mathrm{A}, \mathrm{B}$, and $\mathrm{C}$.

Grades B and C steel tubes used in ultra-supercritical power plant boilers significantly outperform Grade A steel tubes used in supercritical power plant boilers in terms of steam resistance oxidation thickness and fly ash corrosion resistance. ${ }^{10}$ Yet, the high-end grades (i.e. Grades B and C) can technically substitute for the low-end grade (i.e. Grade A), although 'Grade B is about double the price of Grade A, and Grade C is about triple the price of Grade A'. ${ }^{11}$ As shown in Table 2, subject imports are mostly concentrated in Grades B and C steel tubes. However, during the period of investigation (POI) for dumping calculation (i.e. July 2010 till June 2011), $79.9 \%$ of the domestic production is allocated for Grade A products and only $20.1 \%$ for Grades B and C (with 'trivial' sales of Grade C).

Based on the evidence from 2008 to 2010, MOFCOM explained that the domestic industry situations improved in terms of, inter alia, indicators such as domestic sales, market share, capacity, output, labor productivity, salary per head, and net 
Table 3. Chinese AD/CVD investigations with recurring issues

\begin{tabular}{|c|c|c|c|c|}
\hline Investigation & $\begin{array}{l}\text { MOFCOM } \\
\text { initiation }\end{array}$ & $\begin{array}{l}\text { MOFCOM final } \\
\text { determination }\end{array}$ & $\begin{array}{l}\text { WTO consultation } \\
\text { request }\end{array}$ & $\begin{array}{l}\text { WTO report } \\
\text { adoption }\end{array}$ \\
\hline $\begin{array}{l}\text { China-Fasteners } \\
\text { (DS407) }\end{array}$ & 29 Dec. 2008 & n.a. & 7 May 2010 & n.a \\
\hline $\begin{array}{l}\text { China-GOES } \\
\text { (DS414) }\end{array}$ & 1 June 2009 & 11 April 2010 & 15 Sept. 2010 & 16 Nov. 2012 \\
\hline $\begin{array}{l}\text { China-X-Ray } \\
\text { Equipment (DS425) }\end{array}$ & 23 Oct. 2009 & 23 Jan. 2011 & 25 July 2011 & 24 Apr. 2013 \\
\hline $\begin{array}{l}\text { China-Broiler } \\
\text { Products (DS427) }\end{array}$ & 27 Sept. 2009 & 7 Sept. 2010 & 20 Sept. 2011 & 25 Sept. 2013 \\
\hline China-Autos (DS440) & 6 Nov. 2009 & 15 Dec. 2011 & 5 July 2012 & 18 June 2014 \\
\hline $\begin{array}{l}\text { China-HP-SSST } \\
\text { (DS454, DS460) }\end{array}$ & 8 Sept. 2011 & 9 Nov. 2012 & $\begin{array}{c}20 \text { Dec. } 201213 \\
\text { June } 2013\end{array}$ & 28 Oct. 2015 \\
\hline $\begin{array}{l}\text { China-Cellulose Pulp } \\
\text { (DS483) }\end{array}$ & 6 Feb. 2013 & 4 April 2014 & 15 April 2014 & n.a. \\
\hline
\end{tabular}

Note: 'n.a'. stands for not available, as the case did not lead to the establishment of a Panel since MOFCOM terminated the provisional AD duties after the request for consultation from the European Union.

Source: Based on Mitchell and Prusa (2016: 318).

cash flow from operating activities. On the other hand, the domestic market showed signs of deterioration with respect to many indices including inventories, domestic sales price, domestic sales revenue, profits, net cash flow, and capital investment. For example, domestic sales revenue declined by $61.07 \%$ in 2009 in comparison to 2008. While the revenue recovered by $83.41 \%$ in 2010 , a $15.50 \%$ reduction in the annualized amount of revenue persisting from 2008 to $2010 . .^{12}$

As for the issues that the complainants raised in this case, they deal mostly with the same legal claims as in the previous four $\mathrm{AD}$ disputes brought against China. ${ }^{13}$ As shown in Table 3, ${ }^{14}$ the main reason to have essentially identical legal issues repeated in all these disputes seems to be that the challenged AD measures were imposed over a relatively short period of time. Thus, given the timeframe of the Panels' rulings, MOFCOM did not have sufficient time to incorporate the WTO rulings in its practices before the same issues were challenged again. ${ }^{15}$ However, Canada has initiated a dispute focusing on very similar legal claims in 2014 for

12 Panel Report, China-HP-SSST. para. 7.166.

13 Those disputes are analyzed extensively in Prusa and Vermulst (2014, 2015), Moore and Wu (2015), and Mitchell and Prusa (2016).

14 Table 3 shows seven disputes in total but notice that the first one did not lead to the establishment of a Panel.

15 Mitchell and Prusa (2016: 318-319). 
AD measures that China has introduced against cellulose pulp. This ongoing dispute may suggest that the Chinese authorities have not really changed their procedures since three WTO disputes had reached their final verdict by the time the case on cellulose pulp reached the preliminary stage (in November 2013). At the same time, it is curious that only Canada is a complainant, although AD duties have also been imposed on exports from Brazil and the United States (at an even higher rate than for Canada). Does it mean that the United States does not believe that they would have had a strong case? Time will tell.

Regarding the WTO disputes concerning MOFCOM's AD measures, the most puzzling question is how such controversial practices were not contested until the United States, the European Union, and Japan suddenly decided to sue China in multiple cases within a relatively short time span. The data available from the Global Antidumping Database (Bown, 2016) actually show that those complaining members have been the major target of $\mathrm{AD}$ actions from the very early stage of China's AD system. In fact, Table 4 shows that the United States, the European Union, and Japan are among the top target countries of China's AD actions, since China introduced its AD law in 1997. When AD actions against individual EU member countries are considered together with cases against the European Union, the total number of $\mathrm{AD}$ investigations against the European Union and its members reaches 43, making it the top target (together with Japan), and the European Union, Japan and US are the top three targeted countries. Furthermore, the order of the top three target countries would remain the same if the ranking was based on $\mathrm{AD}$ measures.

As shown in Figure 1, the peak time for China's AD actions was actually between 2002 and 2006, much earlier than the time when MOFCOM's practices were challenged simultaneously by multiple cases in the WTO dispute settlement framework. The mere fact that a WTO member uses many AD actions does not necessarily guarantee more WTO litigations. However, it is very hard to understand why MOFCOM's practices were never challenged until the European Union brought the first ever consultation request against China's provisional $\mathrm{AD}$ measures in China-Fasteners in May 2010. ${ }^{16}$ In fact, it is likely that many early AD measures, especially those implemented with little administrative experience, have suffered from many flaws similar to those ruled in recent cases.

As a matter of fact, India seems to present a similar situation. It is one of the most active AD user in the WTO having initiated $764 \mathrm{AD}$ investigations and imposed 558 AD measures between 1992 and 2015 (Bown, 2016). Still, there are only four consultation requests against India's AD measures and no case has reached

16 China-Fasteners is the very first WTO dispute against China involving AD. Notice that this case did not proceed to the establishment of a Panel because China terminated the provisional AD measures after the consultation request was raised by the European Union. See WTO, G/ADP/N/195/CHN/Rev.1, 2. 
Table 4. China's initiation of AD investigations against other WTO members: 1997-2015

\begin{tabular}{lclc}
\hline \hline Exporter & AD initiations & Exporter & AD initiations \\
\hline Japan & 43 & Saudi Arabia & 3 \\
United States & 42 & United Kingdom & 3 \\
Korea & 35 & Canada & 2 \\
European Union & 26 & Belgium & 1 \\
Chinese Taipei & 16 & Brazil & 1 \\
Russian Federation & 11 & Finland & 1 \\
India & 7 & Iran & 1 \\
Singapore & 7 & Italy & 1 \\
Thailand & 6 & Kazakhstan & 1 \\
Germany & 5 & Mexico & 1 \\
Indonesia & 5 & New Zealand & 1 \\
Malaysia & 4 & South Africa & 1 \\
France & 3 & Ukraine & 1 \\
Netherlands & 3 & Turkey & 1 \\
& TOTAL & 232 & \\
\hline \hline
\end{tabular}

Source: Bown (2016).

the stage of even a Panel being established. ${ }^{17}$ The actual size of the Indian market for products subject to AD measures may explain the lack of WTO disputes, probably for some or even many industry sectors, but surely not for all industries. More importantly though, the share of Indian exports subject to AD measures by key importers is much smaller compared to the equivalent figures for China. For example, this share is only $1.3 \%$ and $3.9 \%$ for the stock of measures in place in 2013 in the European Union and the United States, respectively, while the equivalent shares for Chinese exports are $7.3 \%$ and $9.1 \%$, respectively (Bown, 2014). ${ }^{18}$ Thus, the size of China's exports and its strategic use of AD (i.e. India does not specifically target major exporters) may explain the apparent difference between India and China. In any case, this striking difference of major WTO members in terms of their policies against China's AD actions appears to demand more research in the future.

\section{Key legal findings}

The China-HP-SSST case is notably the only AD dispute against China appealed by complainants. In the China-GOES case appealed by China, the Appellate

17 The cases are India - Anti-Dumping Measures on Imports of Certain Products from the European Communities (DS304); India - Anti-Dumping Measure on Batteries from Bangladesh (DS306); IndiaAnti-Dumping Measures on Certain Products from the Separate Customs Territory of Taiwan, Penghu, Kinmen and Matsu (DS318), and India-Anti-Dumping Duties on USB Flash Drives from the Separate Customs Territory of Taiwan, Penghu, Kinmen and Matsu (DS498).

18 These statistics are based on the total AD, countervailing, and safeguard measures. 
Figure 1. Yearly trend of China's AD actions: 1997-2015

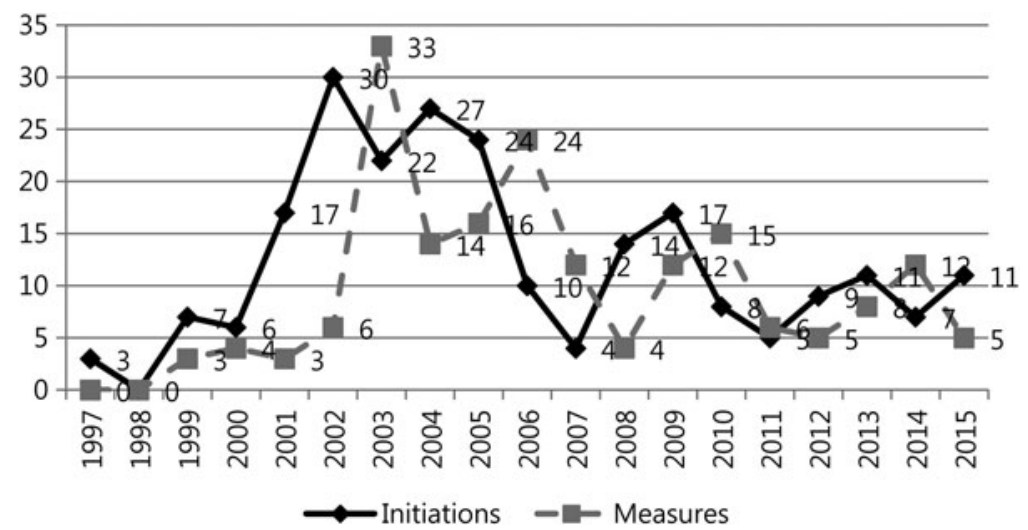

Source: Bown (2016).

Body rejected all of China's appeal claims. The rejections may seem to explain China's choice against appealing the Panel rulings in the subsequent three AD disputes. But in the case at hand, not only China, but also Japan and European Union filed an appeal on the Panel rulings, and China essentially lost almost all legal claims.

As summarized in Table 5, the legal issues raised in this case were also addressed in the previous AD disputes in very similar manners (and most of them appear to be cited in the ongoing dispute China-Cellulose Pulp launched by Canada). We will not repeat the explanation of the Panel and Appellate Body rulings since the reasoning for most legal claims are essentially identical. Instead, we highlight below the points to be distinguished from the earlier cases.

\subsection{Fair comparison in dumping calculation (Article 2.4)}

The European Union contended that China acted inconsistently with Article 2.4, requiring a fair comparison between the export price and the normal value, because MOFCOM failed to account for differences in physical characteristics between Grade C sold in the European Union and Grade C primary boiler tube exported to China. China submitted that the company Salzgitter Mannesmann Stainless Tubes (SMST) never lodged any substantiated request in relation to a fair comparison concerning the relevant sales.

The main issue for the Panel was whether or not SMST actually requested to allow physical differences affecting price comparability within the meaning of Article 2.4 of the Anti-Dumping Agreement. The Panel explained that Article 2.4 offers no guidance as to whether the differences affecting price comparability may be allowed or not.

In fact, SMST's Questionnaire Response did not request any adjustments for differences in physical characteristics. But, in its comments on MOFCOM's 
Table 5. Comparison of legal rulings in the WTO disputes on Chinese AD measures

\begin{tabular}{|c|c|c|c|c|c|}
\hline Substantive legal issues & $\begin{array}{l}\text { GOES } \\
\text { (DS414) }\end{array}$ & $\begin{array}{l}\text { X-Ray } \\
\text { Equipment } \\
\text { (DS425) }\end{array}$ & $\begin{array}{l}\text { Broiler } \\
\text { Products } \\
\text { (DS427) }\end{array}$ & $\begin{array}{l}\text { Autos } \\
\text { (DS440) }\end{array}$ & $\begin{array}{l}\text { HP-SSST } \\
\text { (DS454, } \\
\text { DS460) }\end{array}$ \\
\hline Art.2.2 & & & $\mathrm{X}$ & & $\mathrm{X}$ \\
\hline Cost of production & & & & & $(\mathrm{AB}: \mathrm{X})$ \\
\hline Art.2.4 & & & & & $\mathrm{X}$ \\
\hline \multicolumn{6}{|l|}{ Fair comparison } \\
\hline Arts.3.1/3.2 & $\mathrm{X}$ & $\mathrm{X}$ & $\mathrm{X}$ & $\mathrm{X}$ & $\mathrm{X} / \mathrm{O}$ \\
\hline Price effects & $(\mathrm{AB}: \mathrm{X})$ & & & & $(\mathrm{AB}: \mathrm{X})$ \\
\hline Arts.3.1/3.4 & $\mathrm{X}$ & $\mathrm{X}$ & & & $\mathrm{X} / \mathrm{O}$ \\
\hline Impact analysis & & & & & $(\mathrm{AB}: \mathrm{X})$ \\
\hline Arts.3.1/3.5 & $\mathrm{X}$ & $\mathrm{X}$ & & $\mathrm{X}$ & $\mathrm{X}$ \\
\hline Causation & & & & & $(\mathrm{AB}: \mathrm{X})$ \\
\hline Arts.3.1/4.1 & & & $\mathrm{O}$ & $\mathrm{O}$ & \\
\hline \multicolumn{6}{|l|}{ Definition of domestic industry } \\
\hline Art.6.2 & & & $\mathrm{X}$ & & \\
\hline \multicolumn{6}{|l|}{$\begin{array}{l}\text { Opportunity to meet parties with } \\
\text { adverse interests }\end{array}$} \\
\hline Art.6.5 & $\mathrm{X}$ & $\mathrm{X}$ & $\mathrm{X}$ & $\mathrm{X}$ & $\mathrm{X}$ \\
\hline Non-confidential summaries & & & & & $(\mathrm{AB}: \mathrm{X})$ \\
\hline Art.6.7/Annex I(7) & & & & & $\mathrm{X}$ \\
\hline Rejection of information & & & & & $(\mathrm{AB}: \mathrm{X})$ \\
\hline Art.6.8/Annex II & $\mathrm{X}$ & & $\mathrm{X}$ & $\mathrm{X}$ & $\mathrm{O}$ \\
\hline \multicolumn{6}{|l|}{ Facts available } \\
\hline Art.6.9 & $\mathrm{X}$ & $\mathrm{X}$ & $\mathrm{X}$ & $\mathrm{X}$ & $\mathrm{X} / \mathrm{O}$ \\
\hline Essential facts & $(\mathrm{AB}: \mathrm{X})$ & & & & $(\mathrm{AB}: \mathrm{X} / \mathrm{O})$ \\
\hline Art.7.4 & & & & & $\mathrm{X}$ \\
\hline \multicolumn{6}{|l|}{ Provisional measures } \\
\hline Art.12.2 & $\mathrm{X}$ & $\mathrm{X}$ & $\mathrm{X}$ & $\mathrm{O}$ & $\mathrm{X} / \mathrm{O}$ \\
\hline Public notice & $(\mathrm{AB}: \mathrm{X})$ & & & & \\
\hline
\end{tabular}

Notes: ' $\mathrm{X}$ ' stands for ruling of violation and ' $\mathrm{O}$ ' for ruling of non-violation or to reject complainant's claims.

preliminary dumping disclosure, SMST stated that MOFCOM should have excluded certain sales, because they involved very thin tubes that were not used in primary boiler systems. Also, during the verification process, SMST provided a diagram indicating that tubes sold in the EU markets were thinner than those sold in China and that there were differences in the production processes. In addition, the Panel noted MOFCOM's refusal to exclude the smaller products in its final dumping disclosure and SMST's subsequent arguments that the secondary tubes sold in the EU market should have been excluded from the normal value calculation in its comments on the final disclosure. 
In light of the above facts, the Panel ruled that SMST did request an adjustment, under Article 2.4, to reflect physical differences affecting price comparability. Although SMST initially reported no differences affecting price comparability, 'it should have been clear to MOFCOM that SMST changed its position in this regard during the course of the investigation'. ${ }^{19}$ It explained that, '[a]t a minimum, an objective and impartial investigating authority would have acknowledged the fact that an adjustment was being sought, and considered whether that adjustment was warranted, and if the necessary information had been provided'. Thereby, the Panel found that China acted inconsistently with AD Agreement Article 2.4 by failing to address SMST's adjustment request.

This ruling exemplifies the WTO's attitude towards the trade remedy practices of members for preventing abusive uses. In the EC-Fasteners case, China argued against the European Union that an investigating authority must evaluate any identified differences, regardless of whether a request for adjustment was made or not. ${ }^{20}$ The Appellate Body explained that China's assertion placed an undue burden on an investigating authority to assess each difference in order to determine if adjustment was needed in every case, even without a request by the interested party. Therefore, the investigating authority's duty had become to 'take steps to achieve clarity as to the adjustment claimed and then determine whether and to what extent that adjustment is merited'. ${ }^{21}$ The Panel ruling in the China-HP-SSST case clarified that an investigating authority should be able to incorporate the respondents' change of their positions 'during the course of the investigation'. Even so, it seems to take still many more rulings to elucidate various legal issues such as when the change of firms' position is too late to be reflected for a final determination, what takes to change its position in the investigation, and how much change of positions should be allowed.

\subsection{Injury determination}

Article 3 of the AD Agreement stipulates the rules and requirements for injury determination. The Appellate Body had already explained in China-GOES that Article 3 contemplates a 'logical progression' in the investigating authority's injury determination. ${ }^{22}$ An examination of the volume and price effects pursuant to Article 3.2 and an impact analysis on a domestic industry pursuant to Article 3.4 are linked through a causation and non-attribution analysis between the dumped imports and the injury to the domestic industry under Article 3.5. Based on this explanation, the Appellate Body reviewed the Panel rulings in the case at

19 Panel Report, China-HP-SSST, para. 7.83.

20 European Communities - Definitive Anti-dumping Measures on Certain Iron or Steel Fasteners from China, WT/DS397/AB/R, para. 517 (EC-Fasteners).

21 Ibid., para. 519.

22 Appellate Body Report, China-GOES, para. 128. 
hand and ruled that MOFCOM's assessment was inconsistent with Articles 3.1, $3.2,3.4$, and 3.5.

\subsubsection{Price effects (Articles 3.1 and 3.2)}

Japan and the European Union argued that MOFCOM's conclusion of a significant price undercutting by the imports of Grade B and Grade C was inconsistent with Articles 3.1 and 3.2. Although the Panel found a violation in respect to MOFCOM's failure to account properly for differences in quantities when comparing imported prices with domestic prices of Grade C, it rejected the complainants' other arguments: (1) that MOFCOM failed to consider whether Grade C dumped imports had any price undercutting effect on domestic Grade C (in the sense of placing downward pressure on domestic prices) and (2) that MOFCOM improperly extended its finding of price undercutting in respect of Grades B and C to the domestic like products as a whole, including domestic Grade A.

The Appellate Body disagreed with the Panel's characterization of the obligation under Article 3.2 that price undercutting can be determined simply on the basis of whether there is a mathematical difference, at any point in time during the POI, between the prices of the dumped imports and the comparable domestic products. It emphasized that the term 'price undercutting' in Article 3.2 is used in the present participle, interpreting that the inquiry under Article 3.2 refers to a pricing conduct that is continued over a duration of time, rather than a mere isolated instance of imported goods having been sold at lower prices than the domestic like products. Therefore, it ruled that the price undercutting analysis in Article 3.2 requires 'a dynamic assessment of price developments and trends in the relationship between the prices over the entire POI', rather than a static examination of price difference at any point in time. ${ }^{23}$

In addition, it noted that 'price undercutting' in Article 3.2 is qualified by the word 'significant', dictionary definition of which is provided as 'important, notable, [and] consequential'. ${ }^{24}$ Thus, the significance of the price undercutting should be determined by the magnitude of the price undercutting, which necessarily depends on the circumstances of each case. For this decision, an investigating authority must objectively examine 'all positive evidence relating to the nature of the product or product types at issue, how long the price undercutting has been taking place and to what extent, and, as appropriate, the relative market shares of the product types with respect to which the authority has made a finding of price undercutting'. ${ }^{25}$ The Appellate Body explained that the Panel's approach to focus on a mere mathematical comparison might be a useful starting point but does not provide a proper basis to find sufficient price undercutting. On this

23 Appellate Body Report, China-HP-SSST, para. 5.159.

24 Ibid, at para. 5.161 .

25 Ibid. 
basis, it overturned the Panel's legal interpretation that a significant price undercutting can be found by simply considering whether subject imports sell at lower prices than comparable domestic products.

Turning to the pertinent facts, the Appellate Body noted that MOFCOM failed to explain the basis for its finding that imports of Grade $\mathrm{C}$ were underselling domestic Grade C, since the price of domestic Grade C increased from 20092010, while the prices of dumped imports of Grade C actually fell over that period. It explained that, under the specific facts of this case, MOFCOM could not provide a meaningful basis for the injury analysis because trends in domestic prices by grade had no apparent relationship in terms of magnitude or direction with trends in import prices. On this basis, the Appellate Body concluded that MOFCOM's assessment of a significant price undercutting in regards to Grade C imports from Japan and the European Union, as compared with the price of domestic Grade C, is inconsistent with Articles 3.1 and 3.2.

On the other hand, the European Union argued that, despite the fact that there were 'no relevant imports of Grade A' and that most of the domestic sales were of Grade A, MOFCOM had found that the price undercutting, conducted by imported Grades B and C, has a significant effect on the domestic product as a whole, even without having conducted any cross-grade analysis. The Panel concluded that the existence of price undercutting for the purpose of Article 3.2 must be shown in respect of the dumped imports at issue, not the entire range of goods making up the domestic like product. In this case, the Panel considered that the significance of price undercutting by dumped imports of Grades B and C should be assessed in relation to the price of domestically produced Grades B and $\mathrm{C}$, and not in relation to Grade A products.

The Appellate Body agreed with the Panel that an investigating authority is neither required under Article 3.2 to establish the existence of price undercutting for each product type under investigation, nor with respect to the entire range of goods making up the domestic like product. However, it emphasized the legal standards clarified above that an investigating authority must undertake a dynamic assessment of whether the dumped imports are causing injury. In that regard, it disagreed with the Panel's ruling that MOFCOM was not required to assess the significance of price undercutting by the dumped imports in relation to the proportion of domestic production for which no price undercutting was found.

In this case, MOFCOM indeed found that, during the POI, the dumped imports and domestic sales were concentrated in different segments of the HP-SSST market. While the majority of Chinese domestic HP-SSST production was related to Grade A, the majority of domestic sales was of Grade A. ${ }^{26}$ Thus any objective

26 The market share of Grade A dumped imports was only 1.45\% in 2008 and none thereafter. But, during the POI, the dumped imports of Grades B and C held a market share of around $90 \%$ of its respective market segment (see also Table 2). Ibid. at para. 5.181. 
investigating authority should have taken into account the relevant market shares of the respective product types to examine whether there had been a significant price undercutting by the dumped imports as compared with the prices of the domestic like product. Similarly, an objective analysis of price effects should also have considered significant differences in the prices of these product types. On this basis, the Appellate Body reversed the Panel's finding and concluded that MOFCOM's assessment of a significant price undercutting is inconsistent with AD Agreement Articles 3.1 and 3.2.

\subsubsection{Impact analysis (Articles 3.1 and 3.4)}

Japan and the European Union claimed that MOFCOM was required to undertake a segmented impact analysis of dumped imports on the domestic industry, having found no significant increase in the volume of dumped imports and the price effects with respect to Grades $\mathrm{B}$ and $\mathrm{C}$ only. China refuted this argument by claiming that Article 3.4 requires MOFCOM to assess the dumping impact on the domestic industry as a whole. China pointed out that the two domestic producers making up the domestic industry were producing all three grades, such that it could not distinguish a part of the domestic industry that produced only Grade A.

The Panel recalled its ruling that in finding price undercutting in respect of Grades B and C, MOFCOM was not required by Article 3.2 to consider the effect of subject Grade B and C imports on domestic Grade A. Thus, MOFCOM's failure to undertake a cross-grade price analysis did not preclude a finding that the segment of the domestic industry producing Grade A products could be impacted by dumped imports. Moreover, the Panel noted that MOFCOM defined the domestic industry as one comprising of two domestic producers accounting for a major proportion of total domestic production. Accordingly, it ruled that an evaluation of the state of the domestic industry under Article 3.4 ought to examine the state of those two producers regarding all types of HP-SSST, not just Grades B and C.

In the appeal, given that MOFCOM did not find volume and price effects arising out of imports of Grade A HP-SSST, the complainants argued that Grade A should not form part of the impact analysis under Article 3.4 because it must be considered as a non-attribution factor under Article 3.5. China claimed that the obligation to undertake the impact analysis under Article 3.4 must be distinguished from the obligation to conduct the causation analysis under Article 3.5.

The Appellate Body explained that although Article 3.4 does not prescribe exclusive methodology, an investigating authority's examination of the relationship between the dumped imports and the state of the domestic industry should enable the authority to derive an understanding about the impact of the dumped imports on the domestic industry as a whole. Even though the authority is required to examine the impact of dumped imports on the domestic industry pursuant to Article 3.4 , it is not required to demonstrate causality specifically mandated by Article 3.5 . 
In this case, MOFCOM did not make a finding of price undercutting in respect of Grade A, since there were no imports of Grade A after 2008. The Appellate Body noted that the Panel ruling states 'a limited finding of price undercutting will have obvious implications for an authority's assessment of whether dumped imports caused material injury to the domestic industry [but] this is an assessment to be made pursuant to Article 3.5, rather than 3.4'. ${ }^{27}$ It emphasized that Article 3.4 requires the evaluation of all relevant economic factors and indices having a bearing on the state of the industry. It further stated that such evaluation must provide a 'meaningful basis' for an injury analysis. Therefore, an investigating authority should consider the relative market shares of product types found with price undercutting; and, for example, the duration and extent of price undercutting, and price depression or price suppression. The Appellate Body reversed the Panel in its interpretation of Articles 3.1 and 3.4 to the extent that the Panel found that the results of the inquiries under Article 3.2 are not relevant to the impact analysis under Article 3.4.

\subsection{Disclosure of essential facts (Article 6.9)}

Japan and the European Union contended that China acted inconsistently with Article 6.9 because MOFCOM failed to disclose any information relating to: (i) the specific cost and sales data used to calculate normal value and export prices underlying the margin calculations; (ii) adjustments to these data, for instance, to take account of taxes and freight; and (iii) information on the calculation methodology, including the formulae used in calculations, the data applied in these formulae, and the methodology applying these data to construct normal value, export price, and production costs.

Noting the ruling in China-Broiler Products that, if the essential facts the authority is using are in the possession of the respondent, even a narrative description of the data cannot ipso facto be considered insufficient disclosure, ${ }^{28}$ the Panel decided that Article 6.9 does not mandate disclosures containing the entirety of the essential facts when the respondent has the possession of the relevant essential facts. On this basis, unlike the previous disputes, the Panel in this case rejected the EU claim that MOFCOM had to disclose a spreadsheet 'duly completed with the data actually relied on by the investigating authority'. ${ }^{29}$ It explained that even a narrative description would suffice in the appropriate circumstances in case such description does not leave uncertainty as to the essential facts under consideration.

The Appellate Body disagreed with the Panel and ruled that it does not suffice for an investigating authority to simply disclose 'the essential facts under consideration'. It explained that the authority must disclose the essential facts that 'form 
the basis for the decision whether to apply definitive measures'. Because a party could not know which facts the authority selected among the facts originally provided by the interested party, the mere fact that the investigating authority referred to data in the possession of an interested party would not be enough to disclose the essential facts for a decision to apply definitive measures. After reversing the Panel ruling on the principle for disclosing the essential facts, the Appellate Body reviewed MOFCOM's preliminary and final dumping disclosures. Then, it concluded that China acted inconsistently with Article 6.9 of the AD Agreement, because MOFCOM failed to disclose adequately the data underlying its determination of dumping concerning SMST and Tubacex.

This issue was invariably raised in all previous disputes involving the Chinese AD actions and resulted in WTO inconsistency ruling by the Panels. In fact, disclosure of essential facts under Article 6.9 is a typical systemic issue related to the WTO trade remedy system. What constitutes 'essential facts under consideration which form the basis for the decision whether to apply definitive measures' and who should have an authority to determine the scope of 'essential facts' raises a fundamental question for AD investigations. WTO Members adopt a wide variety of practices from disclosing computer programs for calculating dumping margins to merely indicating some statistical data - often blank parts for confidential information. It will take more disputes to elaborate the rules under Article 6.9 but clarifications on the level of disclosure and who is entitled to decide on disclosure (e.g. Panels, national authorities) can potentially have major repercussions, as firms may decide not to disclose much if, for example, WTO Panels can make everything public. When it comes to China, however, it is evident that MOFCOM needs to significantly enhance transparency in terms of its AD system.

It is noted that many of the litigated issues related to transparency of the AD proceedings including accessibility to non-confidential information, disclosure of essential facts, and public notice were presented by a group of WTO Member in the Doha rules negotiation as 'doable' elements to 'recalibrate' the negotiation. ${ }^{30}$

\section{Legal and economic analysis}

Although the dispute involves several procedural and substantive issues, the following discussion focuses on two crucial substantive issues: price undercutting and causation analysis. As the previous AD-related WTO disputes against China focus on similar issues (see Table 5), some of these commonalities will be highlighted in the discussion. Interestingly for the current dispute, the Panel sided with China on the price undercutting issue only for these findings to be reversed by the Appellate Body. The Panel ruled in favor of the European Union and Japan on causation analysis, and these findings were upheld by the Appellate Body. 


\subsection{Price undercutting}

Under this item, the complainants raised three points: (i) improper comparison of import prices and domestic prices of Grade $\mathrm{C}$ products, (ii) price undercutting merely defined as mathematical difference of import prices and domestic prices for Grade $\mathrm{C}$ products, and (iii) extending finding of price undercutting from Grades B and $\mathrm{C}$ to the entire domestic product (i.e. including Grade A).

From an economic perspective, it is curious that so much attention is paid to Grade $\mathrm{C}$ products when there is virtually no domestic production of this variety. As illustrated by the data in Table 2, only in the first six months of 2011 subject imports of Grade C products exhibited a market share lower than $99 \%$ and still above $90 \%$ ! And at the same time, import and domestic prices moved in opposite directions, with the domestic price of Grade C increasing $112.80 \%$ between 2009 and 2010 while import prices were decreasing (although both prices decreased over the period 2008-06/2011). Given these divergent trends, it is instructive (and correct) for the Appellate Body to have placed considerable emphasis on the need to assess the continuing existence of undercutting. It explicitly clarified that '[a]n examination of such developments and trends includes assessing whether import and domestic prices are moving in the same or contrary directions, and whether there has been a sudden and substantial increase in the domestic prices'. ${ }^{31}$ This argument mirrors the discussion in Mitchell and Prusa (2016) on how investigating authorities often use trend analysis to compare prices. In this specific case, if MOFCOM had done one, it would have detected a 'non-obvious trend analysis' (in the words of Mitchell and Prusa, 2016) where prices of domestic and imported goods move in opposite directions (see Figure 2 in Mitchell and Prusa, 2016, with opposite labels as it is the domestic price to have increased in the case at hand). A negative correlation per se would not be a sufficient condition to discard the possibility of undercutting but a more thorough analysis would be required, which would also have had to consider 'the trivial volume of domestically produced Product C'. ${ }^{32}$ Unfortunately, the data discussed in the various public documents are very limited and do not allow further considerations on the absolute value and difference between import and domestic prices.

Based on the public documents, we can infer that price undercutting was established for Grade B. However, it is puzzling how MOFCOM may have been able to conclude that price undercutting was present for the entire domestic product. The very fact that there were no imports of Grade A products in 2009-06/2011 implies that no price undercutting for this product was taking place (and imports only represented $1.45 \%$ of the market share in 2008). At the same time, it is also worth emphasizing that most domestic production of the subject good is of the Grade A variant (i.e. $79.9 \%$ during the POI). A possible way to explain 
Figure 2. Imports of subject products

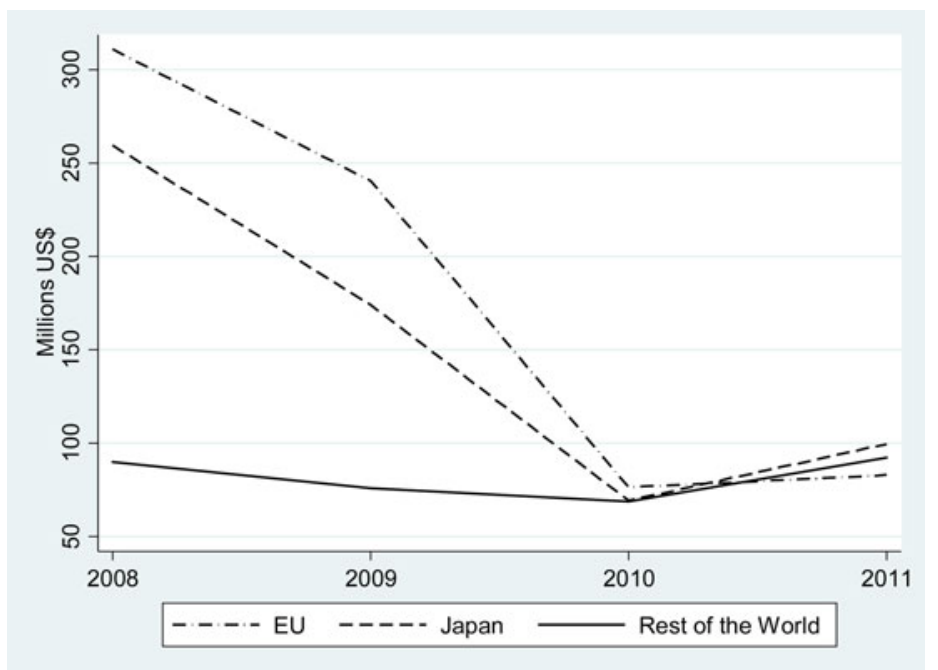

Source: data from Comtrade, based on the 6-digit HS tariff lines 730441 and 730449 as listed in Bown (2016).

MOFCOM's conclusion of undercutting at the industry level would be the consideration of cross-grade price correlations. However, MOFCOM did not provide any evidence of such correlations and simply stated that 'price correlation is a clear consequence of the ability of subject imports of the high-end grades (Grades $\mathrm{B}$ and $\mathrm{C}$ ) to substitute for the low-end grade (Grade A)'. ${ }^{33}$ However, Panel and Appellate Body rejected this simplistic statement.

Interestingly, the discussion above is reminiscent of the analysis done by Prusa and Vermulst (2014) in the China-GOES case. When reflecting on the shortcomings of MOFCOM's price effects' analysis, they also concluded that 'one wonders how much analysis was actually involved in [China's] price effects "analysis". But the similarities do not stop here, Prusa and Vermulst (2015) also emphasize the differences between the varieties of imported products and those produced domestically, as MOFCOM had failed 'to account for the variations in the product mix' of chicken parts in the China-Broiler Products case.

As a result of the arguments just presented, we wonder whether MOFCOM has properly defined the domestic like product. HP-SSST involve three different variants in terms of technical characteristics. In particular, '[s]teel tubes used in ultra-supercritical power plant boilers ([Grade B] and [Grade C]) significantly outperform steel tubes used in supercritical power plant boilers ([Grade A]) in the aspects of steam resistance oxidation thickness and fly ash corrosion 
resistance'. ${ }^{34}$ Although higher grades can substitute for the low-end grade (i.e. Grade A), the existing substantial price differences between these products may render this technical substitutability irrelevant. In fact, footnote 333 of the Panel report states that 'Grade B is about double the price of Grade A, and Grade C is about triple the price of Grade A' and China has not disputed this claim from Japan (see footnote 333). This argument is forcefully made by the Appellate Body as well in paragraph 5.263 when discussing MOFCOM's finding on price correlation. Still the European Union and Japan did not raise any issue relating to the definition of product and industry, while the issue of industry was raised in the dispute China-X-Ray Equipment. As a matter of fact, Moore and Wu (2015) summarize one of the EU's allegations in this case as whether the Chinese authority had 'appropriately defin[ed] the boundaries of the product scope of the investigated sector when undertaking its price effects analysis and its analysis of the state of the domestic industry'. ${ }^{35}$ Still, even in the China-X-Ray Equipment case the European Union did not challenge the product definition although it noted that 'there is a wide and recognizable gap between high- and low-energy scanners' which leads to 'very large disparities in price', 36 just as in the present case. Moore and Wu (2015) suggest that this may be due to the lesson the European Union learned from the EU-Footwear case brought by China against the European Union. In that case, the Panel left ample margins of maneuvering for the investigating authorities to determine 'like' products. As Moore and Wu (2015) speculated regarding the HP-SSST case, ongoing at the time, this issue 'will be a recurrent theme in future WTO disputes' (page 284).

Still, the scope of product under investigation has also some bearing on the complainants' claim related to impact analysis in relation to Articles 3.1 and 3.4. In particular, the European Union and Japan claimed, among other things, that 'MOFCOM improperly considered the impact of subject imports on the domestic industry as a whole, in respect of all three product grades, even though it had only found price effects in respect of Grades B and C'. ${ }^{37}$ Article 3.4 requires an 'examination of the impact of the dumped imports on the domestic industry concerned shall include an evaluation of all relevant economic factors and indices having a bearing on the state of the industry' but the Panel found it 'unclear ... how a determination of injury in respect of the domestic industry as a whole-including an evaluation of the state of that industry as a whole-may be premised, from the outset, on the exclusion of a given segment of that industry'. ${ }^{38}$ While we agree that a given segment of the industry should not be excluded at the outset (once

34 Appellate Body Report, China-HP-SSST, para. 5.264.

35 For this case, the issue was whether low-energy and high-energy scanners are distinct products or not.

36 Panel Report, EU-Footwear, para. 7.16.

37 Panel Report, China-HP-SSST, para. 7.145.

38 Ibid., para. 7.154. 
the domestic like product had been defined as it had been), the shares in Table 2 would prompt a careful consideration of how imports of Grades B and C can be taken to affect a domestic industry that is heavily (i.e. around $80 \%$ ) concentrated on the production of Grade A, given that no cross-price correlation between these grades has been established. With little changes in the imports' market shares of Grades B and C between 2009 and 2010, the overall market share of imports for like products plummeted by about $45 \%$ as a result of lower demand for these grades accompanied by an increase in demand for Grade A products, which was only met by domestic production. The Appellate Body reversed the Panel's decision on this point because it had reversed the other aspects of the Panel's decision, on which this item relied upon.

In fact, while the AD Agreement defines the term 'like product' to be used for dumping calculation and injury determination in Article 2.6, it does not provide any rules concerning how to set forth the scope of the product under investigation, or 'subject product'. 39 The scope of the like product can be determined only after the scope of subject product has been clearly defined. Investigating authorities often employ a rather broad scope of subject products so as to avoid circumvention and increase protection effects, as shown in this case. But such practices make subsequent investigations much more complicated due to the difficulties to ensure fair comparison of dumping elements and an objective assessment of injury.

This problem has been addressed in the Doha rules negotiation. Some WTO members proposed to include only 'products under the same conditions of competition' as the product under consideration. ${ }^{40}$ Another proposal specified that the product under consideration must compete in the same geographical market in the same period. ${ }^{41}$ The proposal to distinguish distinct product under consideration suggested examining 'the physical characteristics of the imports, including technical specifications and quality, and their market characteristics, including end uses, substitutability, pricing levels and distribution channels'. ${ }^{42}$ These efforts denote the need for clarification on this issue. Yet, the fact that there has not been any serious initiative to revive the Doha negotiation after the Nairobi Ministerial Conference in 2015 seems to indicate prolonged systemic ambiguity on this matter.

\subsection{Causation analysis: non-attribution}

A real challenge of antidumping investigations is conducting causation analysis, which is required by Article 3.5. The issue is how to single out dumping as the cause of injury to the domestic industry. Ideally, proper econometric tools should 
be employed so that (most) factors can be appropriately controlled and the role of dumping is clearly identified. Unfortunately, data requirements and the technicalities of the methodologies do not make econometric work a standard toolkit in antidumping investigations (see Prusa and Sharp, 2001, for an example of econometric methods applied to a US antidumping investigation). At the same time, the current case provides an example of a very superficial analysis on the part of MOFCOM, which puts too much emphasis on the market shares reported in Table 2. And again, this aspect has been the subject of other Panel's decisions in previous trade disputes targeting Chinese AD rulings. For example, in the China-X-Ray Equipment dispute the Panel identified some shortcomings in MOFCOM's causation analysis related to the failure of the investigating authority 'to consider "known facts" failure "to consider evidence relating to other factors'. ${ }^{43}$ Similarly, Qin and Vandenbussche (2016) in analyzing recourse by the United States in the China-GOES dispute, raise the need to engage in some form of econometric analysis to establish what the counterfactual situation would have been had dumping not occurred.

As a matter of fact, the statistics on market shares must also be complemented with data on import volumes, which are graphed in Figure $2 .{ }^{44}$ The significant reduction in import levels from the European Union and Japan without substantial changes in import market shares of Grade B and C products is consistent with a significant decline in consumption of these grades (as mentioned in the Panel report). At the same time, the report states that the apparent consumption of Grade A increased" 45 and that '[ $t$ ]he capacity and output of the domestic industry of like products have increased'. ${ }^{46}$ And as discussed previously, there is no clear evidence of cross-grade price correlations. These considerations make it difficult to conclude that there is prima facie evidence to prove that dumping from the European Union and Japan can be considered the prime cause of injury to the domestic industry. Thus, a more in depth analysis is required.

Furthermore, it is not clear that the domestic industry is in such a distressed situation given that 'from 2008 to 2010, domestic sales and market share of the domestic industry of like products have both increased. The capacity and output of the domestic industry of like products have increased synchronously. Driven by capacity and output growth, job creation and labor productivity of the domestic

43 Panel Report, China-HP-SSST, para. 7.16.

44 Notice that the values reported in Figure 2 are very different from those discussed in Section 2, which are derived from the European Commission Press Release IP/13/772. Although products were defined at the 8-digit level of the HS classification, comparability of the HS classification across countries forces us to use data at the 6-digit level, which contains more products than specifically those subject to AD measures in. Also the volumes reported by China in its submission to the WTO (see document G/ADP/N/237/CHN) are very different (i.e. $68 \%$ and $23 \%$ imports of the products from Japan and the EU, respectively). However, these shares refer only to the period of investigation that runs from July 2010 to June 2011.

45 Panel Report, China-HP-SSST, para. 7.203.

46 Ibid., para. 7.166. 
industry of like products also increased. Against the general backdrop of rising labor costs in domestic markets, salary per head in the domestic industry of like products showed an upward trend' ${ }^{47}$ In fact, these indicators all point to relatively good conditions for the domestic industry during the POI.

It is true that it is not all rosy for the domestic industry since 'EOP [end of period] inventories of the domestic industry of like products was rising year on year ... From 2008 to 2010, revenue decline on an annualized basis was $15.50 \%$... Unit operating margin decreased $56.39 \%$ annually. As a consequence, pretax profits and net cash flow from operating activities of the domestic industry of like products both dropped, $67.47 \%$ and $47.78 \%$ respectively on an annualized basis. Shrinking pretax profits resulted in lower ROI for the domestic industry of like products ... sales revenue dropped by $0.38 \%$ year on-year ... Unit operating margin decreased $52.50 \%$ compared with the same period of 2010. As a consequence, pretax profits of the domestic industry of like products dropped by $72.19 \%$ compared with the same period of 2010.'48 However, these relatively adverse conditions should be analyzed in light of the facts discussed above (e.g. Table 2 and Figure 2), as they are consistent with increased output from domestic sources. This comment sounds familiar with similar arguments made by the Panel in the China-X-Ray Equipment dispute in which ' 9 of the 16 indicator of the state of the industry were found to be positive rather than negative' (Moore and $\mathrm{Wu}, 2015$, page 262). In fact, that Panel determined that MOFCOM should have considered the impact of the Chinese producer capacity expansion, rising inventories, and possibly aggressive pricing strategy (Moore and Wu, 2015: 264).

In conclusion, not only MOFCOM did not provide a thorough causation analysis but even the limited data publicly available cast serious doubts on whether dumping of Grades B and C products from the European Union and Japan can be considered to be the root problem for the adverse conditions of the domestic industry described in the previous paragraph. Reliance on market shares certainly cannot be taken as an attempt of a serious causation analysis.

\section{Conclusion}

China introduced its AD law in 1997 and has been a relatively intense user of the AD system since the accession to the WTO in December 2001 (see Figure 1). Yet it is only in 2010 that the first WTO dispute involving AD measures imposed by China was started. Since then, four subsequent disputes in less than six years have involved similar procedural and substantial issues and another one is ongoing. China-HP-SSST is the last one to have reached its conclusion and it focused on the usual issues of fair comparison in dumping calculations, injury

47 Ibid.

48 Ibid. 
determination, and disclosure of essential facts. One further common aspect of all these disputes is that the rulings of the WTO Panels and Appellate Body have been consistently and overwhelmingly in favor of the complainants.

So far, China appears to have constrained its AD actions probably because it exports massively unbalanced amounts to other trading partners. For example, over the period 1995-2015 Chinese exports have been targeted by 100, 80, and $142 \mathrm{AD}$ measures by the US, EU, and India, respectively. Instead, the Chinese government has imposed AD measures only 34, 20, and 7 times against the US, EU, and India, respectively (Bown, 2016). ${ }^{49}$ Other than relatively less frequent, China's $\mathrm{AD}$ actions have not shown any notable distinction from the patterns of major $\mathrm{AD}$ users. ${ }^{50}$

In the coming years, it is very likely that China will come to rely more on AD actions if the trade conflicts against its major trading partners such as the United States and European Union become more serious due to the controversies over market economy status and overcapacity in heavy industries. Moreover, AD actions driven by retaliatory purposes may increase as the Chinese domestic market becomes larger. ${ }^{51}$ As a matter of fact, the AD Regulations of China even stipulates 'corresponding measures' against any country or region that discriminatorily imposes AD measures on exportation from China. ${ }^{52}$ That will inevitably lead to more WTO disputes concerning China's AD measures in the coming years.

Against the backdrop of such possibly increased use of AD measures by China, one would hope that the rulings of WTO Panels and Appellate Body since 2010 will serve to clarify once and for all how the WTO AD Agreement should be interpreted and applied by MOFCOM. It should be the case that this body of jurisprudence will now be the rule in all of subsequent MOFCOM's investigations and that five disputes were needed just because their overlapping timeframe did not allow China to rectify its practice before a new dispute was begun. Hence, the case on HP-SSST should have been the last part of growing pains, although the current dispute initiated by Canada may signal otherwise (if the final verdict will be in Canada's favor).

\section{References}

Blonigen, B. A. and C. P. Bown (2003), 'Antidumping and Retaliation Threats', Journal of International Economics, 60(2): 249-273.

Bown, C. P. (2014), 'Temporary Trade Barriers Database: Update through 2013', mimeo.

49 China also imposed $12 \mathrm{AD}$ measures against individual member states of the European Union.

$50 \mathrm{In}$ fact, it has been noted that there was no particular divide between developed and developing countries in terms of AD policies. See for example Zanardi (2006: 616).

51 Blonigen and Bown (2003) showed a stronger capacity to retaliate AD actions with larger domestic markets.

52 Article 56, Anti-dumping Regulations of the People's Republic of China, http://english.mofcom.gov. cn/aarticle/policyrelease/domesticpolicy/200502/20050200017435.html (accessed 2 June 2016). 
(2016), 'Global Antidumping Database', The World Bank, http://econ.worldbank.org/ttbd/gad/ (version Q4_2015).

Mavroidis, P. C., P. Messerlin, and J. Wauters (2008), The Law and Economics of Contingent Protection in the WTO, Cheltenham: Edward Edgar.

Mitchell, A. and T. Prusa (2016), 'China-Autos: Haven't We Danced this Dance Before?', World Trade Review, 15(2): 303-325.

Moore, M. and M. Wu (2015), 'Antidumping and Strategic Industrial Policy: Tit-for-Tat Trade Remedies and the China-X-Ray Equipment Dispute', World Trade Review, 14(2): 239-286.

Prusa, T. and D. Sharp (2001), 'A Simultaneous Equations Approach to Antidumping Injury Investigations', Journal of Forensic Economics, 14(1): 63-78.

Prusa, T. and E. Vermulst (2014), 'China - Countervailing and Anti-dumping Duties on Grain Oriented Flat-rolled Electrical Steel from the United States: Exporting US AD/CVD Methodologies through WTO Dispute Settlement?', World Trade Review, 13(2): 229-266.

- (2015), 'China-Anti-Dumping and Countervailing Duty Measures on Broiler Products from the United States: How the Chickens Came Home to Roost', World Trade Review, 14(2): 287-335.

Qin, J. and H. Vandenbussche (2016), 'China-Countervailing and Antidumping Duties on Grain Oriented Flat-Rolled Electrical Steel from the United States, Recourse to Article 21.5 by the United States (DS414): It is time to clarify the standards of price suppression and price depression for antidumping and countervailing duty measures', mimeo.

Zanardi, M. (2006), 'Antidumping: A Problem in International Trade', European Journal of Political Economy, 22(3): 591-617. 